Tropical Journal of Pharmaceutical Research January 2017; 16 (1): 127-134

ISSN: $1596-5996$ (print); 1596-9827 (electronic)

(c) Pharmacotherapy Group, Faculty of Pharmacy, University of Benin, Benin City, 300001 Nigeria.

All rights reserved.

Available online at http://www.tjpr.org

Original Research Article

http://dx.doi.org/10.4314/tjpr.v16i1.16

\title{
Effect of Carica papaya (Linn) aqueous leaf extract on pharmacokinetic profile of ciprofloxacin in rabbits
}

\author{
Grace E Ukpo ${ }^{1 \star}$, Mbang A Owolabi ${ }^{1}$, Ngozi OA Imaga ${ }^{2}$, Oluwafunke O Oribayo ${ }^{1}$ \\ and Akpobomen J Ejiroghene ${ }^{1}$
}

${ }^{1}$ Natural Product Research Group, Department of Pharmaceutical Chemistry, Faculty of Pharmacy, ${ }^{2}$ Department of Biochemistry, Faculty of Basic Medical Sciences, College of Medicine Campus, University of Lagos, Lagos, Nigeria

${ }^{*}$ For correspondence: Email: gukpo@unilag.edu.ng; Tel: +234 8034299869

Revised accepted: 17 December 2016

\begin{abstract}
Purpose: To investigate the fate of ciprofloxacin, after concomitant administration with the aqueous leaf extract of Carica papaya, which herbal practitioners in Nigeria have found helpful in the treatment of painful crisis in sickle cell anaemia (SCA) patients.

Method: Thirteen rabbits were fasted for $12 \mathrm{~h}$ and given by oral route $20 \mathrm{mg} / \mathrm{kg}$ ciprofloxacin (control group); after a 3-week crossover period, the animals were given $500 \mathrm{mg} / \mathrm{kg}$ aqueous extract of Carica papaya followed by $20 \mathrm{mg} / \mathrm{kg}$ ciprofloxacin (treatment group). Blood samples were collected over a period of $0-24 \mathrm{~h}$ post-dosing, and pharmacokinetic profile of ciprofloxacin in plasma sample determined using a validated high performance liquid chromatography (HPLC) method.

Results: Time to attain maximum plasma ciprofloxacin concentration $\left(T_{\max }\right)$, lag time and clearance $(C L / F)$ were higher in the treated group; all other pharmacokinetic parameters showed significant decrease in the treated group $(p<0.005)$ compared to the control group. The slow rate of elimination of ciprofloxacin in the control group $\left(0.32 \pm 0.11 \mathrm{~h}^{-1}\right)$ compared to the treated group $\left(0.21 \pm 0.07 \mathrm{~h}^{-1}\right)$ was not due to kidney impairment as plasma creatinine level indicated that kidney function was within normal range $(0.68 \pm 2.78 \mathrm{mg} / \mathrm{dl})$.

Conclusion: The results of the study show that there is interaction between ciprofloxacin and Carica papaya. This interaction can be avoided by taking ciprofloxacin at least $3 \mathrm{~h}$ prior to administration of the leaf extract of C. papaya.
\end{abstract}

Keywords: Carica papaya, Ciprofloxacin, Sickle cell anaemia, Herb-drug interaction, Pharmacokinetics

Tropical Journal of Pharmaceutical Research is indexed by Science Citation Index (SciSearch), Scopus, International Pharmaceutical Abstract, Chemical Abstracts, Embase, Index Copernicus, EBSCO, African Index Medicus, JournalSeek, Journal Citation Reports/Science Edition, Directory of Open Access Journals (DOAJ), African Journal Online, Bioline International, Open-J-Gate and Pharmacy Abstracts

\section{INTRODUCTION}

The use of herbal preparations for medicinal purposes is in parallel with conventional drugs in some populations. Also, fortification or concurrent administration of conventional drugs with herbal preparation is on the increase. It is known that herbs can affect body functions; therefore when taken concurrently with conventional drugs, interactions are possible.
Thus a great concern has arisen on possible drug-herb interaction.

Ciprofloxacin is a fluoroquinolone antibiotic with excellent activity against gram positive and gram negative bacteria as well as Mycobacteria. Oral absorption of this drug has been reported to be affected by its metal cation complexation (Figure 1) which has been extensively studied for antacids [1-3] mineral supplement [4] and milk products $[5,6]$. However, literature on its 
interaction with ciprofloxacin is lacking. Ciprofloxacin is well prescribed for the treatment of infections associated with sickle cell anaemia (SCA): a hereditary blood disorder caused by a single amino acid substitution [Glu $\rightarrow$ Val] at the sixth position of the $\beta$-chain haemoglobin. Similarly, herbal preparation of the leaf of Carica papaya is in good use, traditionally for the relief of painful crisis associated with SCA in Nigeria.

Carica papaya L., (Caricaceae) which is widely cultivated for its edible melon-like fruit is available throughout the year [7]. Phytochemical studies show C. papaya to contain vitamin C, vitamin $\mathrm{E}$, pectin, carotinoids, alkaloids, carpain, nicotine, flavonols, tannins, terpinenes, enzymes papain and chymopapain [8,9]. These enzymes are similar to pepsin and help to digest protein in the body, used to relief indigestion, dyspepsia, reducing enlarged tonsils [9]. Flowers of $C$. papaya are used in the treatment of jaundice [personal communication] and inner bark used for sore throat [10]. The extract of unripe fruit and dried leaves of $C$. papaya have been reported to possess antisickling properties, thus used as an antisickling agent in the management of SCA in Western Nigeria [10,11].

The frequent use of ciprofloxacin and $C$. papaya in the management of SCA in Western Nigeria with no literature on their possible interaction prompted our study. We therefore investigated any possible interaction between these agents.

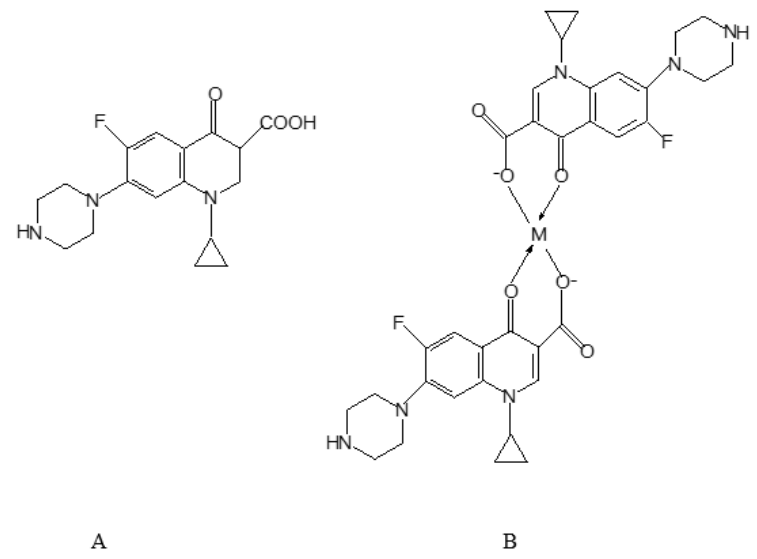

Figure 1: Structure of ciprofloxacin (A) and ciprofloxacin-metal chelate complex (B).

\section{EXPERIMENTAL}

\section{Plant material}

The leaves of Carica papaya were collected from a farm in Lagos, Nigeria in August, 2012 and identified by Mr. Usang Felix of the Forestry Research Institute of Nigeria (FRIN) where a voucher specimen (FHI: 106994) has been deposited. The leaves were dried at room temperature and ground into powder. The powdered leaf, $500 \mathrm{~g}$ was extracted by exhaustive Soxhlet extraction into water for $24 \mathrm{~h}$ (pH 6.4). The aqueous crude extract was freeze dried to obtain a weight of $237.15 \mathrm{~g}$ (47.43 $\% \mathrm{w} / \mathrm{w})$. The crude extract residue was stored at $4{ }^{\circ} \mathrm{C}$ until used.

\section{Animals}

Thirteen rabbits weighing between 1.8 and $2.2 \mathrm{~kg}$ were obtained from an open market and housed in a well-ventilated Laboratory Animal Centre of the College of Medicine of the University of Lagos, Nigeria under standard laboratory condition (12:12 h dark/light cycle). This study was approved by the Health Research and Ethics Committee (HREC) of the College of Medicine of the University of Lagos, Nigeria (CM/HREC/PHM/09/16/014).

The animals were cared for and used in accordance with the Institute of Laboratory Animal Research (ILAR) guidelines for care and use of animals in experimental studies [12]. The animals were allowed to acclimatize for 21 days during which they had free access to commercial pellet diet (Pfizer Feeds, Ibadan, Nigeria, Plc.) and water ad libitium.

\section{Chemical reagents}

All reagents were of analytical grade from Sigma Chemical Co. (St Louis, MO) unless otherwise stated. Ciprofloxacin hydrochloride reference standard was a gift from Swiss pharma Nigeria. Ciprofloxacin tablets $\left(\right.$ Ciprogem $^{\circledR}$ ) were purchase from a pharmaceutical shop in Lagos metropolis. De-ionized distilled water was used throughout the study. Tinidazole, potassium dihydrogen phosphate, tetrabutylammonium hydroxide, nitric acid, hydrochloric acid were from the British Drug House (BDH), Poole, England.

\section{HPLC instrumentation and chromatographic conditions}

The HPLC System was (Agilent 1100 series pump (Serial No DE 43630403, Product No G1311A, Hewlett Packard, Germany) equipped with Rheodyne 7725i injector (USA) coupled to UV detector (Serial No JP43826101 product No G1314A, Japan). The degasser (Serial No JP40720373, Product No G1379A, Japan) was used to remove possible gas in the mobile phase. The chromatographic responses were recorded by Agilent ChemStation Software (Agilent technologies, USA) running on Compaq 
compatible personal computer (Hewlett Packard) with an Inlet Pentium processor operating at $2799 \mathrm{MHz}$ under Microsoft window operating environment and a pin writer hp DeskJet 5652 printer. The chromatographic separation was performed at column temperature of $25^{\circ} \mathrm{C}$ on an inert silica $\mathrm{C}_{18}$ zorbax SB column, $5 \mu \mathrm{m}$ particle size, $250 \mathrm{~mm} \times 4.6 \mathrm{~mm}$ i. d. protected by a Lichrospher Si 60 guard column $30 \mathrm{~mm} \times 4.6 \mathrm{~mm}$ i.d., which was placed between the injector and the analytical column. The $\mathrm{pH}$ meter was Thermo Orion, model 420A (serial No. 071838, Beverly, MA, USA).

The mobile phase consisted of $\mathrm{pH} 3.5$ phosphate buffer $(2 \mathrm{mM})$ : acetonitrile $(60: 40 \mathrm{v} / \mathrm{v})$ distributed by the gradient pump at a flow rate of $1.0 \mathrm{ml} / \mathrm{min}$ and the effluent monitored by the ultraviolet detector at $278 \mathrm{~nm}$. The phosphate buffer was prepared fresh each day of the experiment and consisted of potassium dihydrogen phosphate, tetrabutylammonium hydroxide and phosphoric acid in water.

\section{Atomic absorption spectrophotometer operating conditions}

The composition of metals in the leaves of $C$. papaya were analyzed using atomic absorption spectrophotometer (Buck Scientific, Model 210VGP AAS, USA) equipped with deuterium background corrector and air-acetylene flame atomizer. The instrument was optimized by altering the wavelength, slit width, lamp current and sample energy for each metal to give maximum signal strength (Table 1). The spectrophotometer was calibrated using 100 and $1000 \mu \mathrm{g} / \mathrm{l}$ of zinc working standards prepared in de-ionized water. Calibration curves of absorbance values versus concentration for each metal were constructed from different concentration (0 to $3000 \mu \mathrm{g} / \mathrm{l}$ ) of freshly prepared specific metal in de-ionized water. Except for $\mathrm{Na}$ and $\mathrm{K}$ that were determined by emission mode, all other metals were determined by absorption mode.

\section{Measurement of mineral cation content of Carica papaya}

The apparatus used for this study were thoroughly washed and rinsed with de-ionized water. They were thereafter soaked in $10 \%$ $\mathrm{HNO}_{3}$ for $24 \mathrm{~h}$ and again rinsed severally with de-ionized water and kept to dry in a dust free room. The determination of the metals in the leaves of $C$. papaya followed a standard procedure as described by [13]. Briefly, $2 \mathrm{~g}$ of powered leaves of $C$. papaya was sieved and subjected to dry ash in a clean porcelain crucible in a muffle furnace at $550{ }^{\circ} \mathrm{C}$. The resultant dull grey ash was dissolved in $5 \mathrm{ml}$ of $\mathrm{HNO}_{3} / \mathrm{HCl} / \mathrm{H}_{2} \mathrm{O}$ $(1: 2: 3 \mathrm{v} / \mathrm{v} / \mathrm{v})$ and heated gently until brown fumes disappeared. To the ash mixture was added $5 \mathrm{ml}$ of de-ionized water; heated and the colourless solution which was filtered into a $100 \mathrm{ml}$ flask using ashless Whatman filter paper was used for elemental analysis. The concentration of each element in the sample was estimated using their respective standard curve and calculated as $\mathrm{mg}$ metal per $100 \mathrm{~g}$ of the plant material.

\section{Drug dosing and sample collection}

The rabbits were fasted for $12 \mathrm{~h}$ prior to the study. On the day of the study, each animal was given $20 \mathrm{mg} / \mathrm{kg}$ body weight of ciprofloxacin (Ciprogem $^{\circledR}$, Gemini Pharmaceutical, Lagos, Nigeria) by gastric probe. Whole blood, $5 \mathrm{ml}$, was withdrawn from the retro orbital plexus of each animal before (0 hr) and at 0.25, 0.5, 1, 2, 3, 4, 6, $8,10,12$ and $24 \mathrm{~h}$ post dosing into heparinized bottles and centrifuged immediately at $3000 \mathrm{~g}$ for $15 \mathrm{~min}$.

Table 1: Instrumental operating conditions for the determination of metals in Carica Papaya

\begin{tabular}{|c|c|c|c|c|c|}
\hline \multirow{2}{*}{$\begin{array}{l}\text { Metal } \\
\text { ions }\end{array}$} & \multicolumn{5}{|c|}{ Operating conditions } \\
\hline & $\begin{array}{l}\text { Wave length } \\
(\mathrm{nm})\end{array}$ & $\begin{array}{l}\text { Slit width } \\
\text { (nm) }\end{array}$ & $\begin{array}{l}\text { Lamp current } \\
\qquad(m A)\end{array}$ & $\begin{array}{c}\text { Sample energy } \\
\text { (ev) }\end{array}$ & $\begin{array}{c}\text { Instrumental detection } \\
\text { limit }(\mathrm{mg} / \mathrm{l})\end{array}$ \\
\hline $\mathrm{Ca}$ & 422.7 & 0.7 & 4.0 & 3.912 & 0.010 \\
\hline $\mathrm{Cu}$ & 324.7 & 0.7 & 2.0 & 3.938 & 0.005 \\
\hline $\mathrm{Cr}$ & 357.9 & 0.7 & 2.5 & 3.567 & 0.050 \\
\hline $\mathrm{Fe}$ & 248.3 & 0.2 & 15 & 3.436 & 0.050 \\
\hline K & 766.5 & 0.7 & 2.0 & - & 0.010 \\
\hline $\mathrm{Mg}$ & 285.2 & 0.7 & 2.5 & 3.717 & 0.003 \\
\hline $\mathrm{Mn}$ & 279.5 & 0.2 & 3.0 & 3.937 & 0.050 \\
\hline $\mathrm{Na}$ & 589.0 & 0.2 & 5.0 & - & 0.050 \\
\hline $\mathrm{Pb}$ & 283.3 & 0.7 & 3.5 & 2.874 & 0.030 \\
\hline $\mathrm{Zn}$ & 213.9 & 0.7 & 3.0 & 3.237 & 0.005 \\
\hline
\end{tabular}


The plasma was carefully collected using Pasteur pipette and stored frozen at $-80{ }^{\circ} \mathrm{C}$ until assayed. In another study, after a three week washout period, the rabbits were dosed orally with aqueous leaf extract of Carica papaya, 500 $\mathrm{mg} / \mathrm{kg}$ body weight followed $30 \mathrm{~min}$ after with ciprofloxacin, $20 \mathrm{mg} / \mathrm{kg}$ body weight. Blood samples were withdrawn and treated as in the first procedure. Plasma creatinine was also estimated by the method of Perrone et al [14] to eliminate possible interference of kidney function on the results of our study.

\section{Validation studies}

\section{Calibration curve}

Drug-free plasma was spiked with ciprofloxacin standard solution to obtain 2, 4, 6, 8 and 10 $\mu \mathrm{g} / \mathrm{ml}$ with each concentration containing 10 $\mu \mathrm{g} / \mathrm{ml}$ tinidazole as the internal standard. The peak area ratio of ciprofloxacin to tinidazole, was plotted against the corresponding concentration of ciprofloxacin and a linear regression calculated. The calibration study was conducted in 10 replicates.

\section{Precision and accuracy}

Method validation was performed using the frozen drug-free plasma sample with ciprofloxacin, 2 to $10 \mu \mathrm{g} / \mathrm{ml}$. Accuracy, assessed by recovery efficiency $(n=10)$ was determined by comparing the peak area ratio of the spiked plasma with the peak area ratio obtained by direct injection of the standard solutions of the same concentration.

The intra and inter day assays for precision and accuracy were obtained in 10 replicate assays at varying concentrations of 2 to $10 \mu \mathrm{g} / \mathrm{ml}$. The relative standard deviation (RSD) was used for the assessment of accuracy and precision. Working standard solutions were made fresh each day of the assay.

\section{Assay of ciprofloxacin}

The concentration of ciprofloxacin in plasma was determined in 10 replicates by a validated HPLC method [15], with slight modifications. One hundred $\mu \mathrm{l}$ of tinidazole (IS, $10 \mu \mathrm{g} / \mathrm{ml}$ ) was added to $0.5 \mathrm{ml}$ plasma followed by acetonitrile, $1 \mathrm{ml}$, to precipitate protein. The mixture was centrifuged at $3,000 \mathrm{~g}$ for $15 \mathrm{~min}$ and $20 \mu \mathrm{l}$ of the supernatant was injected into the HPLC system for chromatographic separation. The concentration of ciprofloxacin was estimated from the calibration curve using calibration equation of $\mathrm{y}=\mathrm{mx}+\mathrm{C}$.

\section{Pharmacokinetic analysis of data}

The plasma concentration time data was obtained by a one compartmental analysis. The systemic exposure (area under the curve; AUC) was estimated by the trapezoidal rule method for observed values and this was extrapolated to infinity $\left(A \cup C_{0 \rightarrow \infty}\right)$. The pharmacokinetic parameters, which comprised of time to peak plasma concentration $\left(\mathrm{T}_{\max }\right)$, peak plasma concentration $\left(\mathrm{C}_{\mathrm{max}}\right)$, volume of distribution $\left(\mathrm{V}_{\mathrm{d}}\right)$, elimination half life $\left(t_{1 / 2}\right)$, clearance $(C L)$ were estimated with standard formulae [16].

\section{Statistical analysis}

Data are expressed as mean \pm SD (standard deviation). Statistical difference among groups was assessed by the unpaired Student t- test with the level of statistical significance set as $p<$ 0.05

\section{RESULTS}

\section{Assessment of metal ion content in Carica papaya}

The determination of the metal content in the leaves of Carica papaya (Table 2) revealed the presence of $\mathrm{Ca}, \mathrm{Cu}, \mathrm{Fe}, \mathrm{K}, \mathrm{Mg}, \mathrm{Mn}, \mathrm{Na}$ and $\mathrm{Zn}$. The toxic heavy metals - lead and chromium were below the detection limit. The low levels of the toxic heavy metals might be an evident of lack of soil contamination of the plantation sites of the Carica papaya.

Table 2: Mean content of metals in Carica papaya leaf extract

\begin{tabular}{lc}
\hline Mineral & Content \\
\hline $\mathrm{Ca}$ & $1134.50 \pm 17.93$ \\
$\mathrm{Cu}$ & $4.51 \pm 10.71$ \\
$\mathrm{Fe}$ & $363.74 \pm 25.09$ \\
$\mathrm{~K}$ & $1404.70 \pm 11.09$ \\
$\mathrm{Mg}$ & $401.67 \pm 10.41$ \\
$\mathrm{Mn}$ & $5.73 \pm 12.63$ \\
$\mathrm{Na}$ & $142.87 \pm 35.17$ \\
$\mathrm{Zn}$ & $5.27 \pm 17.03$ \\
$\mathrm{~Pb}$ & Not detected \\
$\mathrm{Cr}$ & Not detected \\
\hline \multicolumn{2}{l}{ Values are mean \pm SD in $\mathrm{mg} / 100 \mathrm{~g}(\mathrm{n}=5)$}
\end{tabular}

\section{Validation data}

The calibration curve was linear with a correlation coefficient, $r^{2}$ of 0.9997 and a regression equation of $Y=0.0170 X+0.0019(X$ $=$ concentration of ciprofloxacin and $Y=$ peak area ratio of ciprofloxacin. For the intra or inter day assays ( $n=10$ each), RSD were less than 5 $\%$ in each concentration (Table 3 ), this shows 
precision to be good within the range of concentrations studied. Accuracy expressed as percentage bias was -4.32 or $-5.25 \%$ for the intra and inter day assayed $(10 \mu \mathrm{g} / \mathrm{ml} ; \mathrm{n}=10)$. Accuracy was also assessed from the percent recovery of ciprofloxacin that had been added to plasma. Mean recovery for intra-day assay was $97.15 \pm 0.15$ and $99.77 \pm 0.57 \%$ for the 2 and 10 $\mu \mathrm{g} / \mathrm{ml}$, respectively. The ciprofloxacin solutions in plasma stored frozen at $-20{ }^{\circ} \mathrm{C}$ was stable over the period of experimental analysis. Repeated freezing and thawing of the plasma had no effect on the concentration of ciprofloxacin.

\section{Pharmacokinetics of ciprofloxacin: effect of Carica papaya co-administration}

The mean plasma concentration-time curves of the oral administration of ciprofloxacin, $20 \mathrm{mg} / \mathrm{kg}$ body weight in the control group and the group with concomitant administration of $C$. papaya, $500 \mathrm{mg} / \mathrm{kg}$ body weight are shown in (Figure 2). The pharmacokinetic parameters are summarized in (Table 4); absorption of ciprofloxacin was more rapid in the control group than in the group that consumed $C$. Papaya, which was evident by ciprofloxacin appearing in the plasma of the control group 10 min earlier than in the test group. $\mathrm{C}_{\max }$ was significantly higher $(p<0.005)$ in the control group (3.45 \pm $0.34 \mathrm{mg} / \mathrm{L})$ compared to the treated group (1.71 $\pm 0.41 \mathrm{mg} / \mathrm{L}$ ) indicating a $50 \%$ reduction in its maximum concentration. The corresponding $\mathrm{T}_{\text {max }}$ was found to be longer by $13 \%$ in the treated group than in the control with values of $2.02 \pm$ 0.45 and $1.79 \pm 0.33 \mathrm{~h}$ respectively. $\mathrm{C}_{\max }$ was followed by a concentration decay that could be fitted to a straight line on semi logarithmic scale, indicating first order mode of elimination. Elimination half-life $\left(t_{1 / 2 e l}\right)$ was $3.25 \pm 0.31$ and $2.20 \pm 0.11 \mathrm{~h}$ for control and treated groups respectively being slower by $32 \%$ in the treated group ( $p<0.05$ ). The significant high plasma concentration of ciprofloxacin resulted in significant $(p<0.05)$ increase in AUC in the control group compared to the treated. There apparent volume of distribution $\left(\mathrm{V}_{\mathrm{d}} / \mathrm{F}\right)$ was higher in the control group compared to the treated. Total clearance (CL/F) was found to be $0.13 \pm$ $0.06 \mathrm{~L} / \mathrm{h} / \mathrm{kg}$ and $0.83 \pm 0.10 \mathrm{~L} / \mathrm{h} / \mathrm{kg}$ for control and treated groups respectively.

Table 3: Assay precision and accuracy of ciprofloxacin determination in plasma

\begin{tabular}{lcccc}
\hline $\begin{array}{l}\text { Nominal conc. } \\
(\boldsymbol{\mu g} / \mathbf{m l})\end{array}$ & $\begin{array}{c}\text { Found conc. } \\
(\boldsymbol{\mu g} / \mathbf{m l})\end{array}$ & $\begin{array}{c}\mathbf{R S D}^{\mathbf{a}} \\
(\%)\end{array}$ & $\begin{array}{c}\text { Accuracy }^{\mathbf{b}} \\
(\%)\end{array}$ & $\begin{array}{c}\text { Recovery } \\
(\%)\end{array}$ \\
\hline Intra-day & & & & \\
2 & $1.94 \pm 0.07$ & 3.61 & -3.10 & $97.15 \pm 0.15$ \\
4 & $3.83 \pm 0.14$ & 3.66 & -4.32 & $95.75 \pm 0.57$ \\
6 & $5.88 \pm 0.23$ & 3.91 & -2.31 & $98.93 \pm 0.45$ \\
8 & $7.79 \pm 0.31$ & 3.98 & -2.78 & $97.74 \pm 0.72$ \\
10 & $9.92 \pm 0.45$ & 4.51 & -0.83 & $99.77 \pm 0.57$ \\
Inter-day & & & & \\
2 & $1.98 \pm 0.09$ & 4.55 & -1.00 & $99.37 \pm 0.33$ \\
4 & $3.79 \pm 0.11$ & 2.90 & -5.25 & $94.87 \pm 0.17$ \\
6 & $5.93 \pm 0.24$ & 4.05 & -1.17 & $98.52 \pm 0.32$ \\
8 & $7.94 \pm 0.19$ & 2.39 & -0.75 & $99.42 \pm 0.24$ \\
10 & $9.86 \pm 0.23$ & 2.33 & -1.40 & $98.68 \pm 0.61$ \\
\hline Values are expressed as mean $\pm \mathrm{SD}(\mathrm{n}=10) ;{ }^{\mathrm{a}} \% \mathrm{RSD}=\mathrm{SD} / \mathrm{mean} \times 100 ;{ }^{\mathrm{b}} \%$ accuracy $=\{($ found conc. - \\
nominal conc.)/nominal conc.\}100
\end{tabular}

Table 4: Pharmacokinetic parameters of ciprofloxacin after a single $20 \mathrm{mg} / \mathrm{ke}$ oral dose with or without aqueous extract of Carica papaya

\begin{tabular}{|c|c|c|c|}
\hline \multirow{2}{*}{$\begin{array}{l}\text { Pharmacokinetic } \\
\text { parameter }\end{array}$} & \multicolumn{3}{|c|}{ Mean \pm SD } \\
\hline & Ciprofloxacin & Ciprofloxacin + C. papaya & $P$-value \\
\hline \multicolumn{4}{|l|}{ Absorption } \\
\hline $\mathrm{C}_{\max }(\mathrm{mg} / \mathrm{L})$ & $3.45 \pm 0.34$ & $1.71 \pm 0.41^{* *}$ & $<0.05$ \\
\hline$T_{\max }(\mathrm{h})$ & $1.79 \pm 0.24$ & $2.02 \pm 0.39$ & \\
\hline Lag time (h) & 0.25 & 0.45 & \\
\hline \multicolumn{4}{|l|}{ Elimination } \\
\hline $\mathrm{T}_{1 / 2 \mathrm{el}}(\mathrm{h})$ & $3.25 \pm 0.31$ & $2.20 \pm 0.31^{*}$ & $<0.005$ \\
\hline $\mathrm{K}_{\mathrm{el}}\left(\mathrm{h}^{-1}\right)$ & $0.32 \pm 0.11$ & $0.21 \pm 0.07$ & \\
\hline $\mathrm{F}$ & 0.8614 & 0.3275 & \\
\hline $\mathrm{AUC}_{0-\infty}(\mathrm{mg} \mathrm{h} / \mathrm{L})$ & $23.6 \pm 1.73$ & $11.8 \pm 2.21$ & \\
\hline $\mathrm{V}_{\mathrm{d}} / \mathrm{F} \quad(\mathrm{L} / \mathrm{kg})$ & $2.41 \pm 0.11$ & $1.26 \pm 0.20$ & \\
\hline $\mathrm{CL} / \mathrm{F}(\mathrm{L} / \mathrm{h} / \mathrm{kg})$ & $0.13 \pm 0.06$ & $0.83 \pm 0.104$ & \\
\hline
\end{tabular}




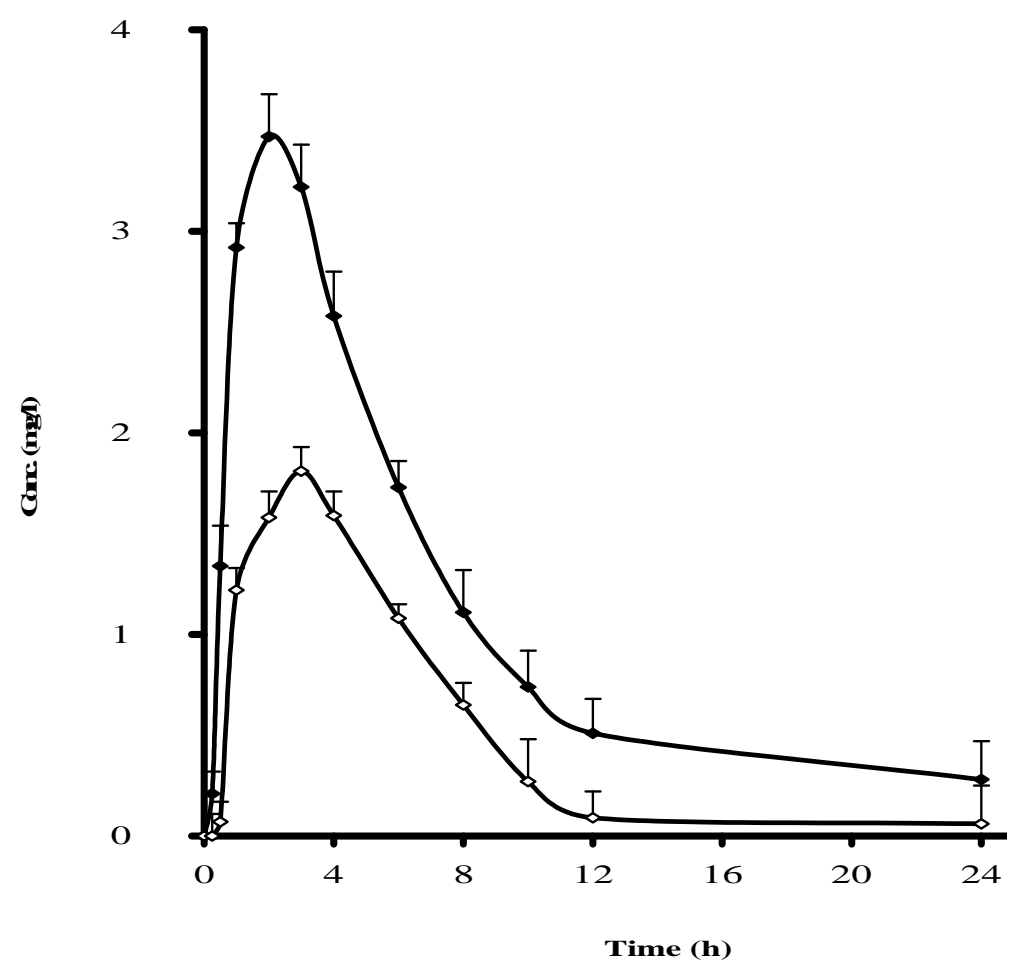

Figure 2: Mean plasma concentration-time curve of the oral administration of ciprofloxacin (20 $\mathrm{mg} / \mathrm{kg}$ ) without - or with - $\bigcirc$ - co-administration of aqueous leaf extract of Carica papaya (100 $\mathrm{mg} / \mathrm{kg}$ )

\section{DISCUSSION}

In recent times, high consumption of herbal remedies has increased the possibility of interaction between conventional drugs and natural products. The mixing of herbal remedies and prescription drugs could be harmful to health, they can alter the way the body metabolizes drugs, cancel the effect of drugs, increase or decrease the amount of drug in the blood stream or its impact to the body. An increase in a drug dosage could occur when an herb component enhances absorption of a drug, or inhibits the enzymes that break down drugs in preparation for elimination. Similarly, a decrease in the amount of drug could occur by herb components binding up the drug and preventing it from getting into the blood stream or by stimulating the production and activity of enzymes that degrades the drugs.

Our study investigated for the first time the possible interaction of Carica papaya on the absorption and pharmacokinetics of ciprofloxacin after concomitant administration. Ciprofloxacin is usually well absorbed but in the presence of agents containing some cations, its absorption is impaired $[4,17,18]$. The leaf of $C$. Papaya, as demonstrated in this study, contains some cations like $\mathrm{Mg}, \mathrm{Ca}, \mathrm{Na}, \mathrm{K}, \mathrm{Fe}, \mathrm{Cu}, \mathrm{Zn}$ and $\mathrm{Mn}$
(Table 2); and is line with the work of [19-21]; with this, the result of our pharmacokinetic study was not unexpected. When ciprofloxacin was coadministered with $C$. papaya, the peak plasma concentration $\left(\mathrm{C}_{\max }\right)$ significantly decreased by $50 \%$ with an increase in time to achieve the peak plasma concentration, $\mathrm{T}_{\max }(p \leq 0.05$, Figure 2). Similar result was obtained from the study of [4] with co-administration of norfloxacin, ofloxacin and ciprofloxacin with $100 \mathrm{mg}$ of elemental iron. The faster a drug is absorbed, the greater the peak plasma concentration and shorter the time to peak plasma concentration [22]. It may therefore imply from our study, that the reduction in $\mathrm{C}_{\max }$ and longer $\mathrm{T}_{\max }$ may have been as a result of reduced rate of absorption in the presence of $C$. papaya which is be supported by the 3 fold increased in lag time observed in this study.

The elimination half-life of ciprofloxacin following co-administration with $C$. papaya was lower than the control. It is known that a drug with a short elimination half-life will be eliminated from the body much more quickly than a drug with longer half-life [22], the results of our study is therefore consistent with increased drug elimination, which may be evident by large drug clearance and reduced apparent volume of distribution in the treated group. The slow rate of elimination of 
ciprofloxacin in the control group $\left(0.32 \pm 0.11 \mathrm{~h}^{-1}\right)$ compared to the treated $\left(0.21 \pm 0.07 \mathrm{~h}^{-1}\right)$ was not due to kidney impairment as the plasma creatinine level that indicate kidney function was within normal range $(0.68 \pm 2.78 \mathrm{mg} / \mathrm{dl})$. There was reduction in the bioavailability of ciprofloxacin in the treated group compared to the control $(p<0.05)$. Reduced bioavailability in our study is supported by reduced rate of absorption and increased rate of elimination. The volume of distribution, $\mathrm{Vd}$ was reduced 2-fold with co-administration of $C$. papaya, implying reduced distribution of ciprofloxacin in this group of animals. This may be attributed to reduced rate of absorption or_low lipophilicity leading to poor membrane permeability through the gut wall.

There are convincing reports that the impairment of the absorption of ciprofloxacin by metal cations is as a result of the formation of a water soluble, non-absorbable metal chelate complex with the 3-carboxyl and 4 keto oxygen groups of the ciprofloxacin molecule which are in close proximity $[23,24]$ thus resulting in very low lipophilicity leading to poor permeation through the gut wall $[1,6,17]$. The presence of cations in the leaves of $C$. papaya may be sufficient in impairing the absorption of ciprofloxacin. Each cation in the leaf extract may result in the formation of ciprofloxacin-metal chelate complex, thus increasing the molecular size and bulkiness of the drug or form a chemical reaction that can lead to poor drug permeation through the gut wall. It is also presumed from the study that the formation of a ciprofloxacin-metal chelate complex is probably the cause of the reduction in ciprofloxacin bioavailability which occurred in the treated group.

\section{CONCLUSION}

Taken together, the findings of this study show that there is interaction between the extract of $C$. papaya and ciprofloxacin based on pharmacokinetic data. This interaction can be avoided by taking the ciprofloxacin at least $3 \mathrm{~h}$ prior to the administration of the leaf extract of $C$. papaya.

\section{DECLARATIONS}

\section{Acknowledgement}

The authors are thankful to Messrs Duncan and Ojobo for their technical assistance and the College of Medicine, University of Lagos, Lagos, Nigeria for allowing the use of the Central Research Laboratory.

\section{Conflict of Interest}

No conflict of interest associated with this work.

\section{Contribution of Authors}

The authors declare that this work was done by the authors named in this article and all liabilities pertaining to claims relating to the content of this article will be borne by them.

\section{Open Access}

This is an Open Access article that uses a funding model which does not charge readers or their institutions for access and distributed under the terms of the Creative Commons Attribution License (http://creativecommons.org/licenses/by 14.0) and the Budapest Open Access Initiative (http://www.budapestopenaccessinitiative.org/rea d), which permit unrestricted use, distribution, and reproduction in any medium, provided the original work is properly credited.

\section{REFERENCES}

1. Frost RW, Lettieri JT, Noe AJ, Shamblen EC, Lasseter K. Effect of alumina hydroxide and calcium carbonate antacids on ciprofloxacin bioavailability. Clin. Pharmac. Ther. 1989; 45: 165-171.

2. Li RC, Nix DE, Schentag JJ. Interaction between ciprofloxacin and metal cations: its influence on physiochemical characteristics and antibacterial activity. Pharm. Res. 1994; 11: 917-920.

3. Yukinori $K$, Kyuichi $M$, Hideo $H$. Interaction of quinolones with metal cations in aqueous solution. Chem. Pharm. Bull. 1996; 44: 1425-1430.

4. Lehto P, Kivisto KT, Neuvonen PJ. The effect of ferrous sulphate on the absorption of norfloxacin, ciprofloxacin and ofloxacine. Brit. J. Clin. Pharmcol. 1994; 37: 82-85.

5. Kuhlmann J, Schaefer HG, Beermann D. Clinical Pharmacology. In Quinolone Antibacterials, Kuhlmann J, Galhoff A, Zeiler HJ, Eds. Springer: Berlin 1998; pp 359361.

6. Zhu M, Wong PYK, Li RC. Effect of oral administration of fennel (Foeniculum vulgare) on ciprofloxacin absorption and disposition in the rat. J. Pharm Pharmacol. 1999; 51(12): 1391-1396.

7. Banerjee $A$, Vaghasiya $R$, Shrivastava $N$, Padh $H$, Nivsarkar M. Antihyperlipidemic effect of Carica papaya L. in Sprague Dawley rats. Nigerian J. Nat. Prod. Med. 2006; 10: 69-72.

8. Tona L, Kambu K, Ngimbi N, Cimanga K, Vlietinck AJ. Antiamoebic and phytochemical screening of some Congolese medicinal plants. J Ethnopharmacol 1998; 61(1): $57-65$ 
9. Kantham S, Tharun KG, Vasu K, Raja RR, Murthy JSN Antihyperlipidemic acitivity of Carica papaya Linn extract in rats. Scientific Journal of Pharmacy, 2011; 1(1): 1618.

10. Ogunyemi CM, Elujoba AA, Durosinmi MA. Antisickling properties of Carica papaya Linn. J. Nat. Prod. 2008; 1: 56-66.

11. Imaga NOA, Gbenle GO, Okochi VI, Akanbi SO, Edeoghon SO, Oigbochie V, Kehinde MO, Bamiro SB. Antisickling property of Carica papaya leaf extract. Afr. J. Biochem. Res., 2009; 3(4): 102-106.

12. Guide for the Care and Use of Laboratory Animals 1996. Institute of Laboratory Animal Research (ILAR) Commission on life Science, National Research Council. Available from: http://www.nap.edu/openbook.php?record_id=5140andp age $=1$ [Last accessed on 2012 Apr 22].

13. Shahidi F, Chavan UD, Bal AK, Mckenzie DB. Chemical composition of beach pea (Lathyrus maritimus L) plant parts. Food Chem. 1999; 64: 39-44.

14. Perrone RD, Madias NE, Levey AS. Serum creatinine as an index of renal function; New insight into old concept. Clin Chem. 1992; 38: 1933-1953.

15. Nix DE, De-Vito JM, Schentag JJ. Liquid chromatographic determination of ciprofloxacin in serum and urine. Clin. Chem. 1985; 31: 684-686.

16. Gibaldi M, Perrier D Pharmacokinetics 2nd ed. Marcel Dekker, Inc. New York. 1982

17. Nix DE, Watson WA, Lener ME, Frost RW, Krol G, Goldstein HR, Lettieri J, Schentag JJ. Effect of aluminium and magnesium antacids and ranitidine on the absorption of ciprofloxacin. Clin Pharmacol Ther, 1989; 46: 700-705.

18. Akerele JO, Okhamafe AO. Influence of oral coadministered metallic drugs on ofloxacin pharmacokinetics. J Antimicrob. Chemother 1991; 28(1): 87-94.

19. Oloyede OI (2005) Chemical Profile of Unripe Pulp of Carica papaya. Pakistan J Nutri 4 (6): 379-381.

20. Bari L, Hassan P, Absar N, Haque ME, Khuda MIIE, Pervin MM, Khatun S, Hossain MI (2006). Nutritional analysis of two local varieties of Papaya (Carica papaya L.) at different maturation stages. Pakistan J Bio Sci 9(1): 137-140.

21. Tigist M, Rao VM, Faye G. Determination of essential and non-essential metals concentration in Papaya (Carica Papaya) seeds, leaves and supporting soil of Odo-Shakiso district in South East Oromia Region, Ethiopia. Int J Res Pharm Chem. 2014; 4(1): 202-216.

22. Jambhekar SS. Physicochemical and biopharmaceutical properties of drug substances and pharmacokinetics. In: Thomas L. Lemke, David A. William, Victoria F. Roche and S. William Zito editors. Foye's principle of medicinal chemistry, 7th edition, Lippincot Williams and Wilkins, Philadelphia. 2003; 61-105.

23. Davies BI, Maesen FPV. Drug interactions with quinolones. Rev. Infect. Dis. 1989; 2: s 1083-1090.

24. Polk RE, Healey DP, Sahai J, Drwal L, Racht E. Effect of ferrous sulphate and multivitamins with zinc on absorption of ciprofloxacin in normal volunteers. Antimicrob. Agents Chemother. 1989; 33: 1841-1844. 